NBER WORKING PAPER SERIES

\title{
LEGACIES IN BLACK AND WHITE: \\ THE RACIAL COMPOSITION OF THE LEGACY POOL
}

\author{
Cameron Howell \\ Sarah E. Turner \\ Working Paper 9448 \\ http://www.nber.org/papers/w9448
NATIONAL BUREAU OF ECONOMIC RESEARCH 1050 Massachusetts Avenue
Cambridge, MA 02138
January 2003

We have benefitted from the comments of seminar participants at the University of Virginia, the University of Texas-Dallas, and the Association for Public Policy Analysis and Management annual meeting. We thank the Andrew W. Mellon Foundation for research support. The views expressed herein are those of the authors and not necessarily those of the National Bureau of Economic Research.

(C)2003 by Cameron Howell and Sarah E. Turner. All rights reserved. Short sections of text not to exceed two paragraphs, may be quoted without explicit permission provided that full credit including notice, is given to the source. 
Legacies in Black and White: The Racial Composition of the Legacy Pool

Cameron Howell and Sarah E. Turner

NBER Working Paper No. 9448

January 2003

JEL No. I2, J1, J15

\section{$\underline{\text { ABSTRACT }}$}

Selective universities regularly employ policies that favor children of alumni (known as "legacies") in undergraduate admissions. Since alumni from selective colleges and universities have, historically, been disproportionately white, admissions policies that favor legacies have disproportionately benefited white students. For this reason, legacy policies lead to additional costs in terms of reductions in racial diversity. As larger numbers of minority students graduate from colleges and universities and have children, however, the potential pool of legacy applicants will change markedly in racial composition. This analysis begins with a review of the history and objectives of the preference for children of alumni in undergraduate admissions. We then consider the specific case of the University of Virginia and employ demographic techniques to predict the racial composition of the pool of potential legacy applicants to the University. Significant changes in the racial composition of classes that graduated from the University of Virginia from the late 1960s through the 1970s foreshadow similar changes in the characteristics of alumni children maturing through the next two decades.

Cameron Howell

Center for the Study of Higher Education

Curry School of Education

University of Virginia

Charlottesville, VA 22903-2495

1ch5x@virginia.edu
Sarah E. Turner

Curry School of Education

Department of Economics

University of Virginia

Charlottesville, VA 22903-2495

and NBER

sturner@virginia.edu 


\section{Legacies in Black and White:}

\section{The Racial Composition of the Legacy Pool}

leg•a•cy (lĕg'C-sē) n., pl. -cies. 1. Money or property bequeathed to someone by will. 2. Something handed on from those who have come before. $[<$ Lat. legare, to bequeath as a legacy.]

-American Heritage Dictionary, Second College Edition

In the world of college and university admissions, the word "legacy" has a peculiar definition that cannot be found in most standard dictionaries. It means "the son or daughter of an alumnus or alumna"- but the practical application of the word, in the admissions community, reveals how it has been derived from its original meaning of inheritance. Graduates of many of America's most elite institutions of higher education bequeath to their sons and daughters a sizable advantage in the admissions process. Known as legacies, these children are admitted at twice the rate of other applicants at some universities, and average SAT scores for legacies are, in some cases, lower than the average scores of their peers. On the surface, these facts raise serious questions for the admissions enterprise, which heralds the ideals of merit and equity.

Debates concerning merit and equity in the admissions process inevitably lead to comparisons of legacy policies and affirmative action, since both policies are forms of preference employed by institutions (Bowen and Bok, 1998; Cross, 1994; Cross and

Slater, 1994; Karabel and Karen, 1990; Larew, 1991; Lederman, 1995; Megalli, 1995;

“Naked hypocrisy," 1997; Wilson, 1995; Woo, 1995). Although comparisons of legacy policies and affirmative action often treat children of alumni and minorities separately, 
the interaction of race and legacy status makes the comparison all the more stark. Historically, the overwhelming majority of alumni from selective colleges and universities have been white, so admissions policies that favor legacies have disproportionately benefited white students. For this reason, legacy preferences potentially decrease racial diversity. This relationship is not static, however. As larger numbers of minority students graduate from selective colleges and have children, the potential pool of legacy applicants will change in racial composition.

In this paper, we examine the relationship between the current racial composition of undergraduate degree recipients and the projected racial composition of the pool of potential legacy applicants. By forecasting changes in the racial distribution of legacies in the admissions pool, this paper focuses on the number of potential legacy applicantsnot on the number of legacies who will actually apply to selective colleges and universities. Therefore, a question for further exploration is whether the realized application behavior among legacies differs by race and whether subsequent matriculation decisions differ by race as well.

This paper begins with an examination of admissions policies for children of alumni. Using the University of Virginia as an example, this paper then employs demographic techniques to predict the University of Virginia’s potential legacy applicants by race. After applying a range of assumptions regarding age- and educationspecific fertility among college graduates, we project that the racial composition of UVa's legacy pool will resemble the composition of the University's contemporary student body by the year 2020. Perhaps of more interest is our finding that the current 
period of admissions activity involves a dramatic transition, with quite sizable changes in the relative representation of African-American youth in the legacy pool expected over the next decade.

Beyond the question of the racial composition of the legacy pool, the more drastic impending change will be the rapid increase in the overall size of the legacy pool—an echo of the expansion of class sizes in the late 1960s and early 1970s. Although the empirical results in this paper are specific to the University of Virginia, the broad demographic results apply to a much wider range of selective colleges and universities. The basic results of this analysis are descriptive: the apparent tradeoff between supporting institutional history with a preference for legacies and furthering racial diversity in the college environment is not as dichotomous as it once was. Coming decades should bring greater racial diversity to the pool of legacy applicants-but differences between the demographic composition of alumni and the demographic composition of incoming groups of college applicants will continue to pose tradeoffs in "crafting a class."

\section{Legacy Policies: Historical Context}

Institutions of higher education have promoted intergenerational attachments since the earliest days of Harvard College. Henry Adams (1907), who graduated from Harvard in 1858, described the familial ties among Harvard alumni in his autobiography:

For generation after generation, Adamses and Brookses and Boylstons and Gorhams had gone to Harvard College, and although none of them, as far as known, had ever done any good there, or thought himself the better for it, custom, social ties, convenience, and, above all, economy, kept each generation in the track (p. 55). 
In the era before increased competition in college admissions, "all alumni children who could demonstrate a minimum level of ability were admitted" to U.S. institutions of higher education (Duffy and Goldberg, 1998, p. 47). This policy attracted no attention until it was threatened. The threat materialized early in the twentieth century, when a series of dynamics increased the quantity and quality of applicants vying for admission to elite colleges. Among these applicants were a growing number of highly-qualified Jewish students. In the 1920s, Ivy League institutions such as Harvard, Yale, and Princeton formalized their admissions policies that favored children of alumni-in order to appease graduate fathers and in order to limit the number of Jewish matriculants (Lamb, 1993; Synnott, 1979).

Later in the twentieth century, a boom in the number of college-age students coincided with improved access to institutions of higher education. Increasingly, students began to apply to and attend colleges and universities outside of their home states (Hoxby, 1999). Geographic integration of selective institutions began in earnest after World War II, when a combination of factors including reduced transportation costs and increased reliance on standardized testing enabled the recruitment of highly talented students from across the nation. Then, beginning in the late 1960s, many institutions entered the era of coeducation, admitting women to undergraduate degree programs. (Coeducation at selective institutions had the dual effects of increasing the number of qualified applicants while also increasing the size of the legacy pool.) During the same decade, colleges and universities responded to the Civil Rights movement by actively seeking to increase minority enrollment. In some Southern states, this era brought an end 
to segregation in higher education. These changes in the gender, race, and geographic representation of applicants increased the overall level of competition for admission to these institutions - infringing upon the traditional advantages of legacy applicants while also making legacy preferences more valuable to their potential recipients. Alumni fathers feared that more and better applicants would surely displace their children in the admissions process.

These fears became especially frenzied at Yale University, when R. Inslee Clark was named the Dean of Admissions in 1965 (Lemann, 1999). The share of alumni sons admitted to the university plummeted from 20 to 12 percent in Clark's first year as dean, and "open warfare" commenced (p. 149). "An apocrypha of Clark horror stories" circulated among the alumni, who felt insulted and threatened (p. 150). William F. Buckley, Jr. lobbied for a position on the Yale Corporation, the university's overseeing board, on the premise that Yale's favoritism of alumni sons should be restored. Kingman Brewster, Jr., the President of Yale, managed to ease tensions among the alumni after he published an apologetic piece in the university's alumni magazine and leaked an internal letter stating that "[t]he only preference by inheritance which seems to deserve recognition is the Yale son" (p. 151).

To this day, a preference by inheritance persists at Yale and other selective colleges. ${ }^{1}$ Three national surveys—conducted by the American Association of Collegiate Registrars and Admissions Officers, American College Testing, the College Board,

\footnotetext{
${ }^{1}$ A key point (often forgotten in a wide array of discussions of admission policy) is that an institution must be truly selective in order for a policy of offering an admissions advantage to legacies to be meaningful.
} 
Educational Testing Service, and National Association of College Admission

Counselors - track the use of legacy policies among college and universities across time (Breland, Maxey, McLure, Valiga, Boatwright, Ganley, \& Jenkins, 1995). The survey results show that both public and private institutions of higher education commonly provide some preference for children of alumni. ${ }^{2}$

The language selected by admissions professionals in describing the advantage accorded to legacies often evokes a "nudge" given to children of alumni, ceteris paribus. ${ }^{3}$ Understanding the magnitude of this advantage or preference is complicated by the possibility that children of alumni may be systematically different from the pool of college applicants at large—since, by definition, legacies are born to graduates of selective colleges and universities (a trait that is often related to excellent academic opportunities at the secondary level and a strong emphasis on academic achievement in the home). Thus, simple comparisons of the admission differences between children of alumni and children of non-alumni may well significantly overstate any legacy advantage in admission.

\footnotetext{
${ }^{2}$ According to the survey data, 23 percent of four-year, public institutions reported favoring children of alumni in 1979. This percentage fell to 14 percent in 1985 and climbed to 16 percent in 1992. 32 percent of four-year, private institutions reported favoring children of alumni in 1979. These percentages changed to 20 and 21 percent in 1985 and 1992, respectively. It is unclear whether these percentage changes represent real alterations of legacy admissions policies in private and public universities or whether these percentage changes may be due to shifts in the number of institutions responding to the national survey.

${ }^{3}$ Jean H. Fetter (1995), a former Dean of Admissions at Stanford University, states Stanford's admissions policy for legacies as follows: "Children of Stanford graduates receive preference in choices among applicants of approximately equal qualifications" (p. 9). Like Stanford, Harvard explains its admissions policy for children of alumni as one where "Harvard-Radcliffe sons or daughters" are preferred only when all other factors are equal (Bromley, 2000).
} 
When one compares admissions trends for legacies to other applicants, however, the observed differences in acceptance rates are sizable. ${ }^{4}$ For example, in Yale's entering classes of 1986 to $1995,19.4$ percent of all applicants were admitted—versus 42.5 percent of children of alumni (Lamb, 1993). Specifically, 22 percent of all applicants to the Class of 1995 were admitted, while 45.2 percent of legacies were admitted. For the Class of 1994, the rate of admission for non-legacies was 19.7 percent and the rate for legacies was 45.4 percent. These data parallel the findings of Bowen and Bok (1998), whose study of twenty-eight selective institutions of higher education measured the competitive advantage of legacies who began college in the fall of 1989. They found that "[t]he overall admission rate for legacies was almost twice that for all other candidates" (p. 28).

Although these admission rates confirm that legacy applicants are admitted more often that their peers, these rates do not reflect the quality of legacy applicants- - their GPAs, standardized test scores, or extracurricular accomplishments. These percentages therefore cannot prove that legacies are more or less qualified than their peers. Shulman and Bowen (2000) contrast the likelihood of admission for differing groups while controlling for differences in SAT scores. For male applicants to one particular institution in their study, legacies enjoyed a 20 percent admissions advantage in 1976compared to a 49 percent advantage for minorities and a 23 percent advantage for athletes. By 1989, the admissions advantage for legacies grew to 23 percent, while the

\footnotetext{
${ }^{4}$ At Princeton University, a 1998 internal report of its Undergraduate Admission Study Group advised that an "accurate measure of the preference accorded legacy applicants is the percentage of legacy applicants offered admission versus the percentage of non-legacy applicants offered admission."
} 
advantage for minorities shrank to 26 percent and the advantage for athletes grew to 30 percent. In 1999, the admissions advantages for legacies, minorities, and athletes were 25 percent, 18 percent, and 48 percent, respectively. Statistics for female applicants yielded similar percentages and changes across time.

There are competing theories that explain the institutional purpose of legacy favoritism. Since the yield rate among legacies is often higher than average, admissions offices can boost their overall yield rates by admitting legacies instead of other, similarly qualified students. Bowen and Bok suggest that legacies are admitted at higher rates in order to preserve "long-term institutional loyalties and traditions" (1998, p. 24). Richard Shaw, Dean of Admissions at Yale, echoes the belief "that tradition is important and generational ties are additional factors that [legacies] have" (Han, 1996). Universities certainly have a vested interest in maintaining distinctive traditions. Children of alumni, having learned of these traditions from their parents, possess a special knowledge of (and a desire to protect) these traditions. Legacies therefore reinforce a university's institutional memory.

Another reason for favoring legacies is purely monetary in nature. Admissions scholars admit this purpose readily. Michele A. Hernandez explains that Dartmouth legacies "are given preferential treatment because the college wants to keep alumni (read: donors) happy" (Gose, 1997). In presenting the advantage of children of alumni at the University of Virginia, Lederman (1995) states that "[1]egacies get a break because Virginia likes to keep its alumni happy—and donating." 
Brittingham and Pezzullo (1990) offer models of donor behavior that capture this relationship between alumni happiness and alumni giving:

The more promising models of individuals' behavior as donors depart from models of pure altruism in favor of exchange models, which attempt to explain donors' motives based on receipt of "goods"—-perquisites, tokens, or honors - in exchange for the gift, and a repeated disequilibrium that follows, leaving the donor with a need to respond to recognition and acknowledgment with yet more gifts.

Exchange models of donative behavior explain that parents of legacies make donations to universities in exchange for a preferential good, the acceptance of their children.

Repeated disequilibrium occurs as these children proceed through and graduate from college, garnering the benefits of an elite education. Exchange models also may explain the donative behavior of legacies themselves, who make gifts to universities in exchange for having been favored in the admissions process.

\section{Legacy Policies and the Racial Composition of the Admissions Pool}

In the long history of higher education in the United States, integration at selective colleges and universities is a very recent event. The children of the men and women who broke the color barrier in the 1960s and 1970s have only recently come of college age. Thus, for many years, admissions policies favoring children of alumni have provided an advantage to students from non-minority, non-immigrant families.

Accordingly, the long-standing policy of offering preference in admission to children of alumni has conflicted with the objective of increasing opportunities for minority students or for the economically disadvantaged.

A number of scholars have criticized legacy policies on these grounds. Megalli (1995) claims that—in 1995-“96 percent of all living Ivy League alumni [were] white” 
(p. 72). He therefore laments the fact that legacy admissions policies at elite colleges and universities benefit families that are largely white. ${ }^{5}$ Guinier deems legacy preferences "proxies for privilege" on the basis that, by definition, they favor children of welleducated families who, it is assumed, possess greater-than-average wealth (2001, p. B12).

It is no surprise, then, that policies favoring children of alumni are often compared to and contrasted with affirmative action policies (Bowen \& Bok, 1998; Cross, 1994; Cross \& Slater, 1994; Karabel \& Karen, 1990; Larew, 1991; Lederman, 1995; Megalli, 1995; "Naked hypocrisy," 1997; Wilson, 1995; Woo, 1995). Although these policies serve different purposes, they often amount to nominally similar kinds of favoritism in the admissions process. Both admissions policies for legacies and affirmative action produce acceptance rates for their respective constituencies that are much higher than acceptance rates for other applicants. In the debate over admissions practices, legacy policies and affirmative action are also juxtaposed because legacy preferences have remained largely untouched while race-sensitive policies have been the subject of repeated legislative and judicial action.

Wilson (1995) maintains that "only a trivial number of white students are actually denied admission to an elite college because of affirmative action; highly qualified white students are far more likely to be squeezed out of a space by a white son or daughter of an alumnus" (p. 93). Although he does not provide a research base to illustrate his

\footnotetext{
${ }^{5}$ It is the case that the elite, historically black colleges and universities (Spelman, Morehouse, Howard, Hampton, Dillard, Xavier, and Fisk) employ legacy policies (Marybeth Gasman, personal communication, December 11, 2001).
} 
claims, Wilson finds it remarkable that "there is no crusade against legacies, especially not among the educated elite of affirmative action critics who are its beneficiaries."

Putting aside the policy comparison between affirmative action and the preference for children of alumni, it is undisputed that the latter has disproportionately benefited white applicants. "[T]he established white admissions advantage replicates itself" through policies that favor children of alumni because the overwhelming majority of alumni from elite colleges and universities are white (Cross, 1994, p. 50). ${ }^{6}$ The racial distribution of alumni at these colleges will not remain so homogenous indefinitely, however. Older cohorts of homogeneous alumni are repeatedly joined by more diverse, younger cohorts of alumni. Minority alumni in these younger cohorts will have children who will grow up and potentially apply to college as legacies. The central question regarding this metamorphosis is one of timing: At what point will the percentage of potential non-white applicants among children of alumni reach a share that is proportional to the percentage of non-white attendees in today's selective colleges and universities?

The remainder of this paper attempts to answer this question by focusing on the University of Virginia as an example. The University's legacy policies, its admissions history, and its current student demographics provide a unique opportunity to forecast changes in the racial distribution of its potential legacy applicants.

\footnotetext{
${ }^{6}$ In addition to the issue of the racial distribution of those admitted to selective institutions, sociologists have studied the extent to which elite universities serve to replicate class distinctions. A study by Farnum (1990) examines the fraction of the protestant elite (represented by inclusion in the social registries of urban areas in the Northeast) graduating from Harvard, Yale, and Princeton. He finds that this share was over 50 percent through much of the early $20^{\text {th }}$ century, before declining precipitously to 30 percent among those graduating in the 1960s. This dramatic change within elite institutions will of course affect future generations of legacy applicants.
} 


\section{Legacy Policies at the University Of Virginia}

One of the nation's premier public universities, the University of Virginia quietly awards an admissions privilege to the children of its alumni. A hint of the importance of alumni status can be found in the information provided by UVa's Common Data Set (University of Virginia Institutional Assessment and Studies, 2000), a listing of facts and figures compiled for use in national surveys. Of the factors affecting first-year admission to the university, "Alumni/ae relation" merits a ranking of "Very important." The only other factors ranked similarly are high school record, Virginia residency, and minority status. The Common Data Set does not account for the precise influence of these factors on admissions decisions, however.

Our conversations with UVa's Dean of Undergraduate Admission, John A. Blackburn, and other admissions officers shed more light on the history, mechanics, and effects of the University's legacy policies. According to Blackburn, the University historically defined a legacy as the child of any student who had been enrolled at the University of Virginia, regardless of degree status. This definition changed in 1979, when the University's Admissions Policy Committee formalized its definition of "legacy" to exclude the step-children and grandchildren of alumni. (The University of Virginia has since reversed this decision, in part. UVa now awards legacy status to alumni step-children.) Furthermore, the Admissions Policy Committee restricted legacy designation to the children of UVa degree-recipients; degree-recipients from all of the University's undergraduate and graduate programs are applicable under this policy. These programs include the School of Architecture, the College of Arts and Sciences, the 
Curry School of Education, the Darden Graduate School of Business Administration, the School of Engineering and Applied Science, the School of Law, the McIntire School of Commerce, the School of Medicine, and the School of Nursing.

UVa also recognizes as legacies the children of Mary Washington College alumnae from the years before 1972. Although the University of Virginia first admitted a woman, Caroline Preston Davis, in 1892, the University's Board of Visitors voted to bar women from attending the school in 1894 (Dabney, 1981; Hitchcock, 1999). Small numbers of women entered the University with special permission until 1920, when women were first admitted to UVa's graduate and professional schools (Dabney, 1981). The undergraduate College of Arts and Sciences did not admit first-year women during this era, so the Commonwealth of Virginia established Mary Washington College in Fredericksburg as a single-sex institution for its women. The University of Virginia eventually opened its doors to undergraduate women in 1970. UVa's policy of treating as legacies the children of Mary Washington's alumnae from before 1972 therefore reconciles its past admissions practices that discriminated against applicants on the basis of their gender.

The primary admissions advantage for UVa's children of alumni is that out-ofstate legacy applicants are considered as if they were in-state students. According to Dean Blackburn, this policy results in the acceptance of approximately 50 percent of outof-state legacies — whereas approximately 27 percent of all out-of-state applicants are accepted by the University. The advantage for in-state legacies is marginal. Again, 
according to Blackburn, approximately 52 percent of in-state legacies are admitted versus 49 percent of all Virginians.

Table 1 illustrates the difference in admission rates for legacy applicants relative to all applicants to the University of Virginia over the past decade. For all applicants to the University of Virginia, about one third of applicants are admitted. Roughly 50 percent of those admitted elect to attend UVa. These percentages are quite different for legacy applicants; the percentage of legacies admitted to UVa is nearly double that for regular applicants. The yield is also appreciably higher. The higher yield among legacies demonstrates that children of alumni are a "safe bet" in the admissions game. Since legacies are more likely to attend UVa, the University's admissions office can increase its overall yield by admitting more children of alumni.

According to Dean Blackburn, the favoritism awarded to UVa legacies is not equivalent to lowering the University's academic standards, however. With the help of the University's Office for Institutional Assessment and Studies, Blackburn has compared the undergraduate grade-point averages of in-state students (excepting legacies), out-of-state students (excepting legacies), and all legacies. Legacy GPAs trailed just behind the GPAs of out-of-state students, and in-state students finished last in the three-way comparison.

Given the University of Virginia's admissions policies for the children of its alumni, the racial composition of these alumni should be noted. The University does not have a long history of admitting racial minorities - especially African Americans. Gregory Hayes Swanson was the first black student at the University of Virginia 
(Dabney, 1981; Hitchcock, 1999). Hayes began his studies in the Law School in 1950, but he dropped out during the next year. Walter N. Ridley was the first African American to receive a degree from the University. He earned his $\mathrm{PhD}$ in Education in 1953. Robert Bland, George Harris, and Theodore Thomas were the first AfricanAmerican undergraduates admitted to UVa, in 1955 (Slater, 1994, 1996). Bland graduated first, in 1959. By 1967, the first year for which UVa has precise statistics on enrollment for minority undergraduates, 19 of the University's 5,096 undergraduates were African Americans (Crystal, 2001).

More recently, the racial distribution of all degree recipients at the University of Virginia has been changing. As Table 2 indicates, the number of African-American degree recipients has doubled since 1980. The number of Asian-American and HispanicAmerican degree recipients has increased much more dramatically. ${ }^{7}$ Although there have been slight fluctuations in the number of white degree recipients, white graduates clearly constitute the majority of students graduating from the University of Virginia.

UVa recognizes the children of Mary Washington alumnae as legacies in order to rectify its history of barring women from its undergraduate classrooms, but the University implements no such policy to account for its long history of segregation. As the statistics for all degree recipients for 1980 to 2001 indicate, UVa's white alumni far

\footnotetext{
${ }^{7}$ To place these percentages in context, it is illustrative to compare the racial composition of undergraduate degree recipients from the University of Virginia to the racial composition of the similarly aged population of the Commonwealth of Virginia. Table 3 lists the number of bachelors-degree recipients at the University of Virginia over the last two decades. For 2000, 70 percent of bachelors-degree recipients were white; African Americans and Asian Americans each represented 10 percent of these graduates. According to the Virginia Employment Commission's census data for 2000, 67 percent of 18-24 year-old Virginians were white, 22 percent were black, and 4 percent were Asian.
} 
outnumber alumni of other races. Therefore, the vast majority of legacy applicants to the University of Virginia are white as well.

Since the number of minority alumni has increased so markedly in the last two decades, it is reasonable to assume that the number of minority legacies will increase in the future - as the children of minority alumni complete high school. How long will it take for this trend to emerge, ending the favoritism of white legacies that has inspired so much criticism in the debate concerning legacy policies and affirmative action? For the year 2001, African-Americans constituted 8 percent of all degree recipients from the University of Virginia. Asian-American students constituted 7 percent of the total, and Hispanic-American students constituted 2 percent. The sections of the paper that follow will calculate the number of children that will be born to University of Virginia alumni, by race. The number of potential legacy applicants will then be calculated, in order to determine the number of years that will be required for the expected number of UVa legacies to reflect the racial distribution found in the most recent class of graduates.

\section{Methodology}

The question of how the size and racial composition of the pool of potential legacy applicants to a university will change over time is, at its essence, a basic application of demographic methods. Demography—-the statistical study of the size, density, and vital statistics of human populations - has been applied to a number of broad policy and commerce purposes, including the prediction of population changes in specific geographic regions and the determination of actuarial liabilities associated with different policies in the insurance industry. In higher education, demography has quite general 
applications in the prediction of enrollment demand or the consideration of the age distribution of faculty. More specifically, it is the life events of marriage, death, and childbearing that combine to determine the intergenerational "links" valued by colleges and university legacy policies.

In the empirical analysis that follows, we focus on data for the University of Virginia, although the same analytics could be applied at any institution. To predict the size and racial composition of cohorts of applicants who are the children of alumni, we begin with the data that are known with certainty: the number of UVa graduates in each academic year. For baccalaureate degree recipients at the University of Virginia (and at other selective institutions), the modal age of degree receipt has remained relatively steady at 22 years of age over a relatively long period of time. For recipients of professional and graduate degrees, age at degree receipt is known with less certainty, inherently requiring some inference and estimation.

For each year, we should identify the number of alumni by age, race, and sex. More formally, denote $\mathrm{L}_{\mathrm{xtj}}$ the number of individuals age $a$ in year $t$ of racial group $j$. We use standard age-specific mortality rates to capture mortality among the alumni

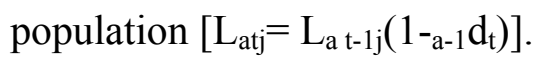

These alumni are "at risk" of childbearing (or may have children already). Knowing the number of alumni by age, race, and sex provides the basis for the estimation of the expected number of alumni children in subsequent years. For each age 
and year, we apply population estimates of fertility. ${ }^{8}$ The application of age-specific birth rates to an age-cohort at any point in time produces the size of the potential legacy pool. Thus, if $b(a)$ is the age-specific birthrate, births in any year $\mathrm{t}$ - what we will call legacy births $\mathrm{B}_{\mathrm{t}}$ - are defined as follows:

$$
B_{t}=\int_{\alpha}^{\beta} b(a) L_{a t} d a
$$

where $\alpha$ is the youngest age of reproduction and $\beta$ is the highest age of reproduction. In practice, age-specific birth rates surely change over time, although as a matter of simplification we set aside this problem in the analysis.

Of course, there will be some mortality among legacies between birth and the age of college application, thus the actual potential applicant pool is somewhat lowermultiplied by ${ }_{0} \mathrm{q}_{18}$, or the probability of surviving from age 0 to age $18 .{ }^{9}$ Again, we assume these parameters are constant over time and racial group. In these calculations, assumptions of race neutrality in mortality within the pool of college graduates seem appropriate and can be shown to be largely innocuous. Thus, the size and racial composition of the potential pool of legacy applicants in any year of admission is largely determined 18 years prior by the fertility behavior among existing age cohorts of alumni.

\footnotetext{
${ }^{8}$ The level and timing of fertility among college-educated women differs from the population at large. Also, within a pool of college students the marriage patterns are likely to differ from the population at large. Most significantly, and discussed later in this section, many selective institutions that employ a preference for legacy admissions were, at one point, all-male. Thus, predicting the pool of legacy applicants requires inferences about the marriage rates and subsequent fertility of wives. In later years, after coeducation, rates of marriage among UVa alumni as well as the gender composition of the class may well affect the size of potential cohorts of legacy applicants.

${ }^{9}$ In this case, we apply a standard survival probability equal to .98782 , which is derived from the total population life table published by the National Center for Health Statistics (2002). This may well overestimate mortality if college graduates have lower child mortality than non-graduates.
} 
An interesting dimension of this empirical problem concerns movement in racial composition of the pool of applicants from one equilibrium to another. Over time, we would, of course, expect the composition of the legacy applicant pool to mirror the composition of the contemporary graduating class, but the long period of fecundity necessarily implies that the transition from one racial distribution to another will require a lag time of nearly one half of a century.

One dimension over which the projection of fertility among cohorts of college students is more difficult than traditional closed-country analyses is that graduates marry both other graduates of the same university and those from outside a given university. The extremes bound this problem, defined by graduates of Institution A marrying only other graduates of Institution A and graduates never marrying other graduates of Institution A. More troublesome analytically is the likely problem that the rate of marriages among graduates changes over time and that this rate may also vary by race. For our analysis of the University of Virginia, this problem is complicated by the changing gender composition of UVa's graduating classes - driven particularly by the introduction of undergraduate coeducation in 1970. We discuss this problem further in the following section.

\section{Empirical Predictions}

Understanding the aggregate trends in degree attainment is the starting point to understanding likely changes in the pool of potential legacy applicants at the undergraduate level. The last four decades have been characterized by substantial changes in both the size and demographic composition of UVa's graduating classes. 
Figure 1 shows the size of the University of Virginia's graduating classes from 1900 to 2000. What stands out in this figure is the period of explosive growth in the overall number of graduates between 1960 and 1980. Over this interval, total degrees conferred at the University increased by a factor of four, while undergraduate degrees increased by a factor of 4.3 (from 572 in 1960 to 2,492 in 1980). Growth has continued in the most recent two decades, but at an appreciably slower pace.

Beyond the changes in the size of the graduating class, the admission of first-year women in 1970 and the racial integration of the undergraduate program are central changes occurring in the last four decades. By 1980, nearly one-half of undergraduate degree recipients were women (see Figure 2). For minorities, particularly African Americans, explicit segregation was eliminated in the 1950s, but minority undergraduates remained less than 3 percent of all undergraduates as late as 1973. Thereafter, the urging of the courts under the Fordice ruling ${ }^{10}$ and the more general social initiative calling for an affirmative response to the history of discrimination and minority underrepresentation in Southern institutions led to a dramatic increase in the share of minority graduates at the University of Virginia (see Figure 3). The share of black graduates reached a local peak of about 8 percent in 1985, experienced a modest decline, and then established a relatively steady proportion between 10 and 12 percent in the last decade.

With these data as a background, it is surely no surprise that minority representation among the pool of potential legacy applicants has been quite low. Very

\footnotetext{
${ }^{10}$ In United States v. Fordice, 112 S. Ct. 2727 (1992), the U.S. Supreme Court ruled that remnants of segregation remained in the structure and admissions policies of Mississippi's system of higher education. As a result, states in the South have applied various corrective measures to end lingering discriminatory effects in their colleges and universities.
} 
few African Americans received degrees from the University of Virginia in the 1960s, thus the number of minorities within the legacy pool has been quite small. Table 4 shows available data on applicants by legacy status and race for 1991 and 2001. In the last decade, the share of legacies among those completing applications has risen markedly (by about 60 percent) from about 4 percent of completed applications to about 6.9 percent of completed applicants. For African Americans, this increase has been even more marked, with African-American children of alumni accounting for less than 1 percent of completed applications in 1991 and nearly 3 percent of completed applicants in 2002. African Americans were dramatically underrepresented in the pool of legacy applicants even in the most recent year, accounting for about 3 percent of this group relative to about 10 percent of the entering student body. At issue, then, is the description of the time path over which a new steady state will be established in which the representation of minorities in the legacy applicant pool will mirror their current representation in the overall student body. To answer this question, we predict the size and composition of the potential pool of legacy applicants using the demographic methods outlined in the prior section.

Several assumptions in the mechanical process of predicting the likely pool of legacy applicants merit brief note. First, data from the University of Virginia's Office of Assessment and Studies provide precise undergraduate graduation figures for African Americans from only 1976 to the very recent past, but it is known that very small numbers of minority students graduated before 1976. Because the size of the graduating cohort as far back as 1965 continues to affect the size of today's potential applicant pool, 
we assume that the number of African American degree recipients declined at a constant rate between 1976 and 1965, reaching 0 at this point. ${ }^{11}$ Similarly, gender data are limited before 1965, so we make an assumption of no women before 1940 (with World War II leading to marked increases in the nursing program) and a simple assumption that the nursing school was $1 / 10$ the size of the program for undergraduate men between 1940 and 1965.

A more significant set of assumptions concerns the appropriate fertility rates and the degree of marriage among university graduates. It is well known that the fertility rates among college graduates differ appreciably from those of women at large, since college graduates typically have fewer and somewhat later births. If there were no marriages among graduates, we would wish to calculate fertility for both male and female graduates. We begin with this proposition, although it is quite plain that the assumption is unrealistic and leads to an overstatement of the growth in the potential legacy pool. In effect, ignoring marriage among graduates of the same institution leads to doublecounting of alumni children. Figure 4 shows the total pool of potential legacy applicants, using the methodology described in the previous section with a range of different assumptions about the extent to which there is overlap among the children of male and female alumni.

The level of marriages between university graduates effectively dampens the expected increase in the size of the legacy pool between 1990 and 2000. Still, the

\footnotetext{
${ }^{11}$ The University of Virginia first awarded a degree to an African American in 1953 (Dabney, 1981; Hitchcock, 1999); however, there was not a consistent rate of minority admission (and, in turn, a consistent rate of degrees produced) until 1965.
} 
magnitude of the increase in the size of the pool is quite striking. Under the marriage assumption that would yield the lowest rate of change (the 75-percent marriage rate), we would still expect growth of about 80 percent over this decade, with a sharp rate of increase persisting through 2005. Data from the University of Virginia Alumni Association indicate that approximately 12 percent of UVa alumni are married to another UVa alumnus or alumna (Helen Dwyer, personal communications, February 18 and 19, 2002). An accurate forecast of the number of UVa's potential legacy applicants may therefore fall between the 0- and 25-percent marriage rates represented in Figure 4.

Figure 5 gets to the substance of the analytic question in this paper, showing the expected increase in the share of African-American legacies in the coming years. While the growth in the share of black students in the legacy pool started more than a decade ago, there appears to be much growth yet to be realized. The share of African Americans in the pool of potential legacy applicants is likely to double in the coming decade, before reaching the plateau of about 9 percent in $2020 .^{12}$ To this end, long-standing images of legacy admissions as disproportionately benefiting white students still hold, but are eroding quickly. This change in the composition of the pool of potential legacy applicants occurs against the backdrop of population demographics that are very different than the composition of entering cohorts, with a quarter-century lag. Since policies favoring children of alumni necessarily reflect the demographic composition of a

\footnotetext{
12 The differential gender composition by race has a curious effect on the likely racial composition of the legacy pool, as African-American women are appreciably more likely to graduate than AfricanAmerican men (and this has been true for a considerable period time). White women have only recently surpassed white men in their representation among college graduates.
} 
college's past graduates, these policies are inevitably in some conflict with the overall demographic composition of current students and applicants.

The significant accomplishment of this analysis is to provide clear calculations of the potential pool of legacy applicants by race at a selective institution that is likely to mirror other institutions in its historical enrollment patterns. In this sense, the demographic evidence presented here has broader applicability than simply providing a case study of the University of Virginia. Beyond predicting potential outcomes, however, policy makers in higher education focus on realized outcomes. To this end, the examination of projections leads naturally to the consideration of the realization of outcomes.

Conversations with UVa's Dean of Admission make clear that the admissions advantage for legacy students accrues only to out-of-state residents and does not create a "double" advantage associated with both legacy and minority status. Because children of alumni may be systematically different from the broader applicant pool in ways that have direct bearing on admission (independent of legacy preference), comparisons of averages need to be conducted with some caution. Table 5 shows the admissions rates and yields for African American and white legacy applicants. What is clear for both groups is that the yield among legacy applicants is appreciably greater than among non-legacies, for both races. Yield is a particularly important variable to consider in the calculus of "crafting a class." ${ }^{, 13}$ Relatively low yield rates for African-American students who are not legacies (most of the minority applicants to selective institutions, historically)

${ }^{13}$ Recent debate concerning yield rates in college admissions has addressed early decision policies (Hoover, 2002) and the practice of rejecting applicants who are not likely to attend (Young, 2002). 
complicate the objectives of admissions officers attempting to achieve diversity in their student populations.

\section{Conclusion and Implications for Policy}

Policies favoring legacies in the admission process may serve legitimate institutional purposes. Among the institutional purposes for providing an admissions advantage to children of alumni is that this preference enables colleges and universities to encourage monetary support and volunteer activity from alumni parents, while also promoting positive intergenerational links within the student community.

This rationale was endorsed, in part, by the U.S. Department of Education's Office for Civil Rights (1990) in its conclusion of a two-year investigation of Harvard's admissions policies. Despite evidence that white legacies were admitted to Harvard at the expense of other racial groups, OCR did not charge Harvard with a violation of Title VI of the Civil Rights Act of 1964. In his letter accompanying OCR's Statement of Findings, Thomas J. Hibino (1990), Acting Regional Director, explained that —although Harvard's legacy policies "disproportionately benefit[ed] white applicants" (p. 7) — the school had "legitimate institutional goals" that were accomplished through its legacy policies (p. 6). These goals included the following: "(1) to encourage alumni volunteer services (such as recruiting prospective students to Harvard), (2) to encourage alumni financial contributions, and (3) to maintain community relations." OCR acknowledged 
"that there are no alternatives to these preferences that could effectively accomplish the same legitimate goals." 14

Our demographic forecasts predict that the once extreme racial imbalance in the composition of the pool of potential legacy applicants will change dramatically in coming decades. Still, it will be some number of years before the representation of AfricanAmerican students in the legacy pool resembles the share of black students in the contemporary student body or the population of college-age students more generally. This lag reflects a tautological law of demographic change: the racial and ethnic composition of the pool of potential legacy students necessarily resembles the composition of past student generations; as such, shifts in the racial and ethnic composition of student populations will be followed, decades later, by similar shifts in the pool of potential legacy applicants.

Although social critics have often juxtaposed affirmative action and legacy preferences in college admissions, it need not be the case that such policies are in absolute conflict, theoretically or empirically. The prerogative of an institution to "craft a class," seeking those students well positioned to further a college's educational goals, is implicit in both policies. To argue that either the consideration of race or the consideration of legacy status in college and university admissions is protected by

\footnotetext{
${ }^{14}$ Legacy policies have also attracted attention during recent judicial inquiries regarding affirmative action. In December of 2001, the University of Michigan defended its affirmative action policies in U.S. District Court (Steinberg, 2001). Judge Eric L. Clay questioned a plaintiff's attorney “why he opposed points for black applicants but did not object to giving points to the offspring of alumni" ( $p$. A27). The attorney answered, 'I'm not aware of a constitutional provision that says you can't discriminate on the basis of an alumni connection." Both the University of California Regents v. Bakke (1978) and the Hopwood v. State of Texas (1996) decisions make note of this tension between affirmative action and legacy policies.
} 
academic freedom and associated case law is to allow the viability that the other policy is protected by the same claims of institutional self-determination.

Legacy policies nevertheless face a self-perpetuated challenge, which is in many respects independent of race. The University of Virginia and its peers must soon reckon with the expanding size of their respective legacy pools. An after-effect of the expansion of graduating classes in the 1960s and 1970s, the increasing size of future legacy cohorts may force admissions offices to reevaluate their favoritism for alumni children. This reevaluation will coincide with other allocative choices that must be made in the face of larger demographic growth. In order to maintain the size of incoming classes, the University of Virginia will be forced to reject an increasing number (and share) of legacies and other applicants. In order to continue admitting comparable numbers (and shares) of legacies and other applicants, the University of Virginia must consider adding spaces in its first-year classes.

Any future threats to legacy admissions policies — and the certain demographic shifts on the time horizon - may lead colleges and universities to examine how preferences for legacies contribute to the vitality and prospects of entering classes more generally: How do legacies contribute to the value of incoming classes, and how does favoring legacies add or subtract from the economical allocation of limited spaces in each incoming class? These are fundamental questions of institutional self-determination in higher education.

The broad policy question of how the inclusion of an admissions preference for children of alumni affects the composition of the entering class and the well being of the 
institution remains, however. Although the changing racial composition of the pool of potential legacy applicants is a significant demographic transition, the increase in the overall size of the pool of potential legacy applicants is, perhaps, the most significant challenge faced by admissions officers trying to balance the demand for preference in admission against broader institutional objectives. The dynamics outlined here for the University of Virginia are, by no means, an isolated institutional transformation. Very similar changes are inevitably facing other selective institutions in the public and private sectors of higher education. 


\section{References}

Adams, H. (1907). The education of Henry Adams. New York: Vintage Books.

Bowen, W. G., \& Bok, D. (1998). The shape of the river: Long-term consequences of considering race in college and university admissions. Princeton: Princeton University Press.

Breland, H. M., Maxey, J., McLure, G. T., Valiga, M. J., Boatwright, M. A., Ganley, V. L., \& Jenkins, L. M. (1995). Challenges in college admissions: A report of a survey of undergraduate admissions policies, practices, and procedures. Sponsored by American Association of Collegiate Registrars and Admissions Officers, American College Testing, The College Board, Educational Testing Service, and National Association of College Admission Counselors.

Brittingham, B. E., \& Pezzullo, T. R. (1990). The campus green: Fund raising in higher education. Washington, DC: ERIC Clearinghouse on Higher Education.

Bromley, S. G. (2000, April 27). Fifteen minutes: The Harvard mafia: Siblings kill to join the family in Cambridge. In Harvard Crimson [On-line]. Available: http://www.thecrimson.com/article.aspx?ref=100721

Cross, T. (1994, Spring). Suppose there was no affirmative action at the most prestigious colleges and graduate schools. Journal of Blacks in Higher Education, 0(3), 44-51.

Cross, T., \& Slater, R. B. (1994-1995, Winter). Alumni children admissions preferences at risk: The strange irony of how the academic achievements of asians may rescue affirmative action for blacks. Journal of Blacks in Higher Education, 0(6), 87-90.

Crystal, C. (2001, December 14). African-American Affairs office has charted successful, 25-year course. Inside UVA, 31(40), pp. 4-5.

Dabney, V. (1981). Mr. Jefferson's university: A history. Charlottesville: University of Virginia Press.

Duffy, E. A., \& Goldberg, I. (1998). Crafting a class: College admissions and financial aid, 1955-1994. Princeton: Princeton University Press.

Farnum, R. (1990). Patterns of upper class education. In P. W. Kingston \& L. S. Lewis (Eds.), The high status track: Studies of elite schools and stratification. Albany, NY: State University of New York Press. 
Fetter, J. H. (1995). Questions and admissions: reflections on 100,000 admissions decisions at Stanford. Stanford: Stanford University Press.

Gose, B. (1997, October 10). Who gets in and why: A former admissions officer tells all. In Chronicle of Higher Education, A45.

Guinier, L. (2001, December 14). Colleges should take "confirmative action" in admissions. Chronicle Review, B10-B12.

Han, Sinae. (1996, October 17). Legacies take Yale traditions in stride. In Yale Daily News Online [On-line]. Available:

http://www.yale.edu/ydn/paper/10.17.96/10.17.96storyno.DB.html

Hibino, T. J. (1990, October 4). Letter to Harvard President Derek Bok RE: Compliance Review No. 01-88-6009.

Hitchcock, S. T. (1999). The University of Virginia: A pictorial history. Charlottesville: University of Virginia Press.

Hoover, E. (2002, January 11). New attacks on early decision. $\underline{\text { Chronicle of Higher }}$ Education, A46.

Hopwood v. State of Texas, 78 F.3d 932 (5th Cir. 1996), cert. denied, 116 S.Ct. 2582 (1996).

Hoxby, C. M. (2002). The effect of geographic integration and increasing competition in the market for college education [On-line]. Available:

http://post.economics.harvard.edu/faculty/hoxby/papers.html

Karabel, J., \& Karen, D. (1990, December 8). Go to Harvard, give your kid a break. New York Times, p. A25.

Lamb, J. D. (1993). The real affirmative action babies: Legacy preferences at Harvard and Yale. Columbia Journal of Law and Social Problems, 26, 491-521.

Larew, J. (1991, June). Why are droves of unqualified, unprepared kids getting into our top colleges? Because their dads are alumni. Washington Monthly 23(6), pp. 10-14.

Lederman, D. (1995, April 28). The special preferences are not limited to blacks. In Chronicle of Higher Education [On-line]. Available: http://chronicle.com/chedata/articles.dir/articles-41.dir/issue-33.dir/33a01601.htm

Lemann, N. (1999). The big test: The secret history of the American meritocracy. New York: Farrar, Straus and Giroux. 
Megalli, M. (1995, Spring). So your Dad went to Harvard: Now what about the lower board scores of white legacies? Journal of Blacks in Higher Education, 0(7), 71-73.

Naked hypocrisy: The nationwide system of affirmative action for whites. (1997-1998, Winter). Journal of Blacks in Higher Education, 0(18), 40-43.

National Center for Health Statistics. (2002, March 21). National vital statistics report, $\underline{50}(6)$, p. 7-8 [On-line]. Available:

http://www.cdc.gov/nchs/data/nvsr/nvsr50/50_06_01.pdf

[Princeton University] Undergraduate Admission Study Group. (1998, October 5).

Report of the Undergraduate Admission Study Group [On-line]. Available:

http://www.princeton.edu/pr/reports/admission_study/adm-report.html

Rosenstock v. The Board of Governors of the University of North Carolina, 423 F. Supp. 1321 (M.D. N.C. 1976).

Shulman, J. L. \& Bowen, W. G. (2000). The game of life: College sports and educational values. Princeton: Princeton University Press.

Slater, R. B. (1994). The blacks who first entered the world of white higher education. Journal of Blacks in Higher Education, 4, 47-56.

Slater, R. B. (1996). The first black graduates of the nation's 50 flagship state universities. Journal of Blacks in Higher Education, 13, 72-85.

Steinberg, J. (2001, December 7). U.S. appeals court hears debate on race-based admissions. New York Times, p. A27.

Synnott, M. G. (1979). The half-opened door: Discrimination and admissions at Harvard, Yale, and Princeton, 1900-1970. Westport, Connecticut: Greenwood Press.

United States v. Fordice, 112 S. Ct. 2727 (1992).

University of California Regents v. Bakke, 438 U.S. 265 (1978).

University of Virginia Institutional Assessment and Studies. (2000). University of Virginia Common Data Set. Available: http://www.virginia.edu/ iaas/cds/cds.htm

U.S. Department of Education's Office for Civil Rights. (1990). Statement of findings. Compliance Review: 01-88-6009. 
Virginia Employment Commission. (2000). Census 2000 Demographic Profiles: State of Virginia SF1 Profile [On-line]. Available:

http://www.velma.vec.state.va.us/vecweb/sflpdffiles/vasf1.pdf

Wilson, J. K. (1995-1996, Winter). The myth of reverse discrimination in higher education. Journal of Blacks in Higher Education, 0(10), 88-93.

Woo, E. (1995, April 30). Belief in meritocracy an equal-opportunity myth; Preferences: It appeals to notion of fairness, but distorts realities of social mobility, historians say. Los Angeles Times, p. A1.

Young, Jeffrey R. (2002, October 11). Group will study practice of rejecting good applicants who might not enroll. Chronicle of Higher Education, A40. 
Table 1: Admissions Statistics for All Applicants and Children of Alumni, University of Virginia, 1991-2002

\begin{tabular}{|c|c|c|c|c|c|}
\hline \multirow[b]{2}{*}{ Year } & \multicolumn{5}{|c|}{ All Applicants } \\
\hline & Applied & Admitted & $\%$ Admitted & Enrolled & Yield (\%) \\
\hline 1991 & 17,087 & 5,534 & $32 \%$ & 2,983 & $54 \%$ \\
\hline 1992 & 15,078 & 5,482 & $36 \%$ & 2,930 & $53 \%$ \\
\hline 1993 & 15,848 & 5,588 & $35 \%$ & 2,928 & $52 \%$ \\
\hline 1994 & 14,921 & 5,429 & $36 \%$ & 2,908 & $54 \%$ \\
\hline 1995 & 15,577 & 5,755 & $37 \%$ & 2,909 & $51 \%$ \\
\hline 1996 & 17,338 & 5,650 & $33 \%$ & 2,834 & $50 \%$ \\
\hline 1997 & 16,728 & 5,712 & $34 \%$ & 2,882 & $50 \%$ \\
\hline 1998 & 16,557 & 5,713 & $35 \%$ & 2,764 & $48 \%$ \\
\hline 1999 & 17,090 & 5,383 & $31 \%$ & 2,678 & $50 \%$ \\
\hline 2000 & 14,472 & 5,282 & $36 \%$ & 2,804 & $53 \%$ \\
\hline \multirow[t]{2}{*}{2001} & 15,052 & 4,860 & $32 \%$ & 2,540 & $52 \%$ \\
\hline & \multicolumn{5}{|c|}{ Children of Alumni } \\
\hline Year & Applied & Admitted & $\%$ Admitted & Enrolled & Yield $(\%)$ \\
\hline 1991 & 689 & 378 & $55 \%$ & 262 & $69 \%$ \\
\hline 1992 & 690 & 402 & $58 \%$ & 273 & $68 \%$ \\
\hline 1993 & 737 & 436 & $59 \%$ & 294 & $67 \%$ \\
\hline 1994 & 767 & 435 & $57 \%$ & 261 & $60 \%$ \\
\hline 1995 & 854 & 499 & $58 \%$ & 329 & $66 \%$ \\
\hline 1996 & 925 & 517 & $56 \%$ & 332 & $64 \%$ \\
\hline 1997 & 971 & 499 & $51 \%$ & 336 & $67 \%$ \\
\hline 1998 & 972 & 493 & $51 \%$ & 330 & $67 \%$ \\
\hline 1999 & 957 & 474 & $50 \%$ & 320 & $68 \%$ \\
\hline 2000 & 949 & 503 & $53 \%$ & 346 & $69 \%$ \\
\hline 2001 & 1,005 & 569 & $57 \%$ & 378 & $66 \%$ \\
\hline
\end{tabular}

Source: University of Virginia Institutional Assessment and Studies 
Table 2: All Degrees Conferred by Race, University of Virginia, 1980-2001

\begin{tabular}{|c|c|c|c|c|c|c|c|c|}
\hline Year & Total & $\begin{array}{c}\text { White } \\
\text { American }\end{array}$ & $\begin{array}{c}\text { African } \\
\text { American }\end{array}$ & $\begin{array}{c}\text { Asian } \\
\text { American }\end{array}$ & $\begin{array}{l}\text { Hispanic } \\
\text { American }\end{array}$ & $\begin{array}{c}\text { Native } \\
\text { American }\end{array}$ & $\begin{array}{l}\text { Foreign } \\
\text { (Non- } \\
\text { resident) }\end{array}$ & $\begin{array}{c}\text { Not } \\
\text { Classified }\end{array}$ \\
\hline 1980 & 4,337 & 3,990 & 198 & 39 & 2 & 3 & 74 & 31 \\
\hline 1981 & 4,460 & 4,137 & 185 & 38 & 6 & 0 & 85 & 9 \\
\hline 1982 & 4,454 & 4,089 & 187 & 48 & 7 & 1 & 84 & 38 \\
\hline 1983 & 4,633 & 4,218 & 219 & 51 & 13 & 3 & 96 & 33 \\
\hline 1984 & 4,526 & 4,050 & 242 & 61 & 15 & 5 & 98 & 55 \\
\hline 1985 & 4,489 & 3,949 & 309 & 74 & 24 & 3 & 93 & 37 \\
\hline 1986 & 4,734 & 4,173 & 281 & 66 & 23 & 2 & 116 & 73 \\
\hline 1987 & 4,830 & 4,160 & 313 & 101 & 24 & 2 & 145 & 85 \\
\hline 1988 & 4,828 & 4,159 & 271 & 134 & 20 & 2 & 148 & 94 \\
\hline 1989 & 4,843 & 4,155 & 270 & 138 & 31 & 3 & 160 & 86 \\
\hline 1990 & 4,930 & 4,119 & 310 & 183 & 37 & 5 & 165 & 111 \\
\hline 1991 & 5,073 & 4,184 & 342 & 208 & 38 & 2 & 182 & 117 \\
\hline 1992 & 5,281 & 4,307 & 402 & 240 & 42 & 1 & 180 & 109 \\
\hline 1993 & 5,261 & 4,102 & 438 & 309 & 54 & 3 & 219 & 136 \\
\hline 1994 & 5,040 & 3,918 & 394 & 317 & 76 & 12 & 162 & 161 \\
\hline 1995 & 5,158 & 3,887 & 459 & 362 & 67 & 6 & 204 & 173 \\
\hline 1996 & 5,203 & 3,832 & 401 & 403 & 66 & 7 & 211 & 283 \\
\hline 1997 & 5,267 & 3,798 & 449 & 376 & 77 & 6 & 222 & 339 \\
\hline 1998 & 5,172 & 3,735 & 411 & 400 & 76 & 12 & 185 & 353 \\
\hline 1999 & 5,426 & 3,795 & 421 & 443 & 108 & 6 & 278 & 375 \\
\hline 2000 & 5,309 & 3,641 & 453 & 414 & 111 & 18 & 295 & 377 \\
\hline 2001 & 5,468 & 3,844 & 417 & 403 & 107 & 10 & 334 & 353 \\
\hline
\end{tabular}

Source: University of Virginia Institutional Assessment and Studies 
Table 3: Baccalaureate Degrees Conferred by Race, University of Virginia, 1980-2001

\begin{tabular}{|c|c|c|c|c|c|c|c|c|}
\hline Year & Total & $\begin{array}{c}\text { White } \\
\text { American }\end{array}$ & $\begin{array}{c}\text { African } \\
\text { American }\end{array}$ & $\begin{array}{c}\text { Asian } \\
\text { American }\end{array}$ & $\begin{array}{l}\text { Hispanic } \\
\text { American }\end{array}$ & $\begin{array}{c}\text { Native } \\
\text { American }\end{array}$ & $\begin{array}{l}\text { Foreign } \\
\text { (Non- } \\
\text { resident) }\end{array}$ & $\begin{array}{c}\text { Not } \\
\text { Classified }\end{array}$ \\
\hline 1980 & 2,492 & 2,324 & 112 & 28 & 1 & 1 & 15 & 11 \\
\hline 1981 & 2,599 & 2,431 & 121 & 28 & 2 & 0 & 15 & 2 \\
\hline 1982 & 2,583 & 2,394 & 116 & 37 & 2 & 1 & 13 & 20 \\
\hline 1983 & 2,734 & 2,505 & 149 & 33 & 11 & 1 & 19 & 16 \\
\hline 1984 & 2,708 & 2,438 & 181 & 48 & 9 & 4 & 20 & 8 \\
\hline 1985 & 2,658 & 2,326 & 231 & 62 & 16 & 2 & 9 & 12 \\
\hline 1986 & 2,772 & 2,458 & 207 & 49 & 15 & 0 & 24 & 19 \\
\hline 1987 & 2,809 & 2,429 & 227 & 79 & 10 & 2 & 21 & 41 \\
\hline 1988 & 2,839 & 2,495 & 170 & 102 & 12 & 1 & 28 & 31 \\
\hline 1989 & 2,799 & 2,416 & 172 & 117 & 19 & 1 & 31 & 43 \\
\hline 1990 & 2,812 & 2,374 & 201 & 149 & 19 & 3 & 29 & 37 \\
\hline 1991 & 2,815 & 2,315 & 221 & 166 & 21 & 1 & 43 & 48 \\
\hline 1992 & 2,989 & 2,404 & 297 & 187 & 29 & 1 & 36 & 35 \\
\hline 1993 & 2,949 & 2,222 & 318 & 241 & 35 & 2 & 54 & 77 \\
\hline 1994 & 2,808 & 2,113 & 291 & 230 & 51 & 8 & 34 & 81 \\
\hline 1995 & 2,857 & 2,078 & 334 & 269 & 38 & 2 & 54 & 82 \\
\hline 1996 & 3,055 & 2,268 & 287 & 295 & 51 & 4 & 62 & 88 \\
\hline 1997 & 2,921 & 2,135 & 284 & 280 & 44 & 3 & 58 & 117 \\
\hline 1998 & 3,044 & 2,250 & 276 & 304 & 54 & 10 & 50 & 100 \\
\hline 1999 & 3,210 & 2,325 & 299 & 344 & 70 & 3 & 70 & 99 \\
\hline 2000 & 3,132 & 2,223 & 327 & 311 & 76 & 8 & 81 & 106 \\
\hline 2001 & 3,221 & 2,341 & 291 & 293 & 63 & 5 & 114 & 114 \\
\hline
\end{tabular}

Source: University of Virginia Institutional Assessment and Studies 
Table 4: Recent Applicant Behavior by Legacy Status, University of Virginia, 1991 and 2002

\begin{tabular}{|c|c|c|c|c|c|c|c|c|}
\hline & \multicolumn{4}{|c|}{1991 Entering Class } & \multicolumn{4}{|c|}{2002 Entering Class } \\
\hline & \multicolumn{2}{|c|}{ Legacy } & \multirow[b]{2}{*}{ Total } & $\%$ & \multicolumn{2}{|c|}{ Legacy } & \multirow[b]{2}{*}{ Total } & \multirow{2}{*}{$\begin{array}{c}\% \\
\text { Legacy }\end{array}$} \\
\hline & No & Yes & & Legacy & No & Yes & & \\
\hline African American & 1,190 & 10 & 1,200 & $0.83 \%$ & 952 & 29 & 981 & $2.96 \%$ \\
\hline Asian American & 1,232 & 7 & 1,239 & $0.56 \%$ & 1,568 & 19 & 1,587 & $1.20 \%$ \\
\hline Hispanic American & 243 & 1 & 244 & $0.41 \%$ & 490 & 19 & 509 & $3.73 \%$ \\
\hline Native American & 17 & 1 & 18 & $5.56 \%$ & 57 & 5 & 62 & $8.06 \%$ \\
\hline Non-resident & 259 & 1 & 260 & $0.38 \%$ & 687 & 1 & 688 & $0.15 \%$ \\
\hline Unclassified & 397 & 10 & 407 & $2.46 \%$ & 759 & 56 & 815 & $6.87 \%$ \\
\hline White American & 10,382 & 583 & 10,965 & $5.32 \%$ & 8,820 & 855 & 9,675 & $8.84 \%$ \\
\hline Total & 13,720 & 613 & 14,333 & $4.28 \%$ & 13,333 & 984 & 14,317 & $6.87 \%$ \\
\hline
\end{tabular}

Source: University of Virginia Institutional Assessment and Studies 
Table 5: Acceptance Rate and Yield by Race and Legacy Status, University of Virginia, 2002

\begin{tabular}{|c|c|c|c|c|c|c|c|c|c|}
\hline & \multicolumn{3}{|c|}{$\begin{array}{c}\text { Offered } \\
\text { Admission }\end{array}$} & \multicolumn{3}{|c|}{$\begin{array}{c}\text { Acceptance } \\
\text { Rate }\end{array}$} & \multicolumn{3}{|c|}{ Yield } \\
\hline & \multicolumn{2}{|c|}{ Legacy } & \multirow[b]{2}{*}{ Total } & \multicolumn{2}{|c|}{ Legacy } & \multirow[b]{2}{*}{ Total } & \multicolumn{2}{|c|}{ Legacy } & \multirow[b]{2}{*}{ Total } \\
\hline & No & Yes & & No & Yes & & No & Yes & \\
\hline African & & & & & & & & & \\
\hline American & 598 & 20 & 618 & $62.8 \%$ & $69.0 \%$ & $63.0 \%$ & $47.2 \%$ & $60.0 \%$ & $47.6 \%$ \\
\hline White & 2,994 & 497 & 3,491 & $33.9 \%$ & $58.1 \%$ & $36.1 \%$ & $56.9 \%$ & $70.8 \%$ & $58.9 \%$ \\
\hline Total & 5,014 & 574 & 5,588 & $37.6 \%$ & $58.3 \%$ & $39.0 \%$ & $52.4 \%$ & $69.5 \%$ & $54.2 \%$ \\
\hline
\end{tabular}

Source: University of Virginia Institutional Assessment and Studies 
Figure 1. Degrees conferred at the University of Virginia, 1900-2000.

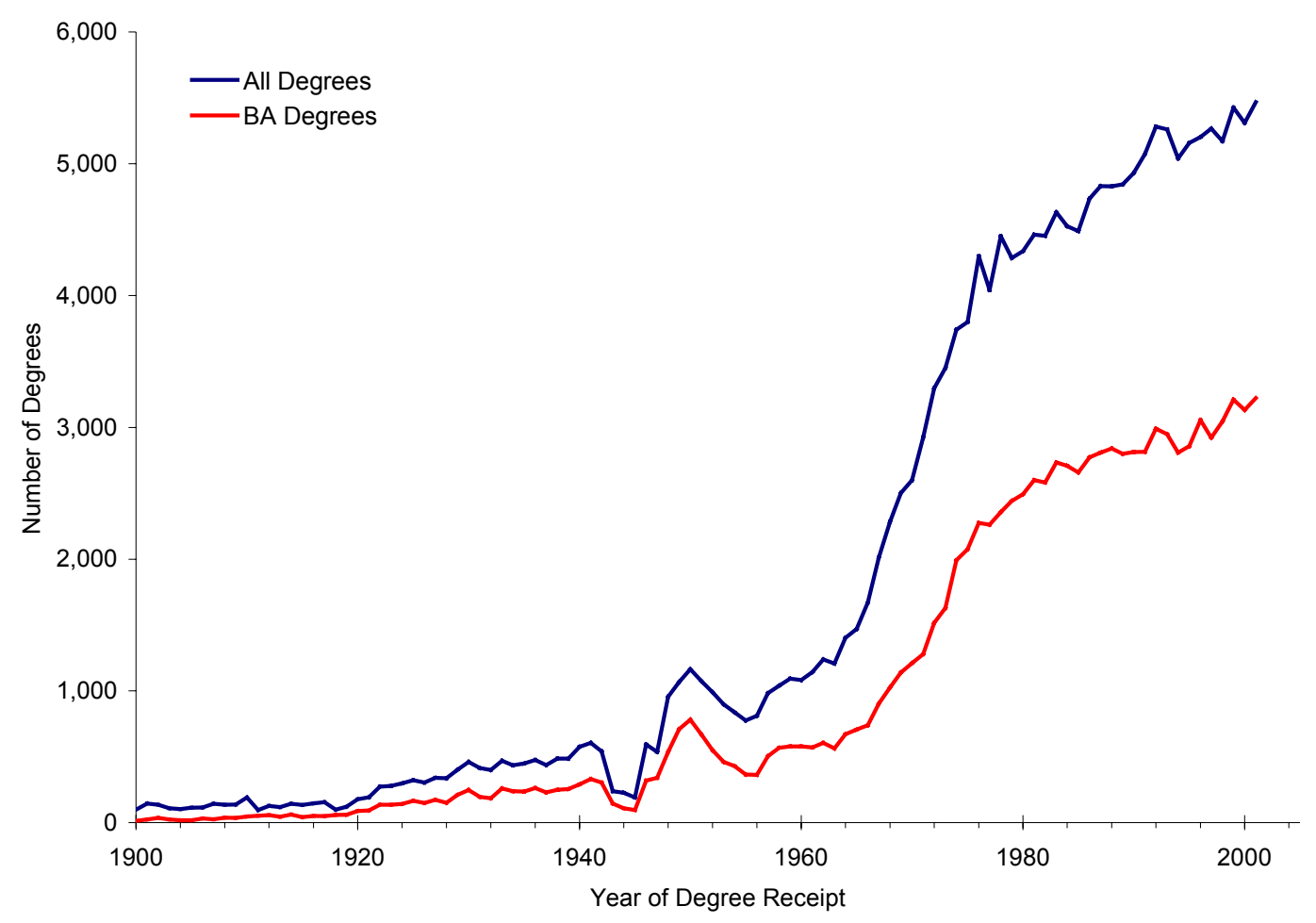

Source: Data from University of Virginia Recipients of Degrees, Volume II, 1900-1919 (Accession \# RG-14/6/1.782), Albert and Shirley Small Special Collections Library, University of Virginia; University of Virginia Catalogue and University of Virginia Record (1920-1956); University of Virginia Office of Assessment and Studies. 
Figure 2. Share of bachelors degrees awarded to women at the University of Virginia.

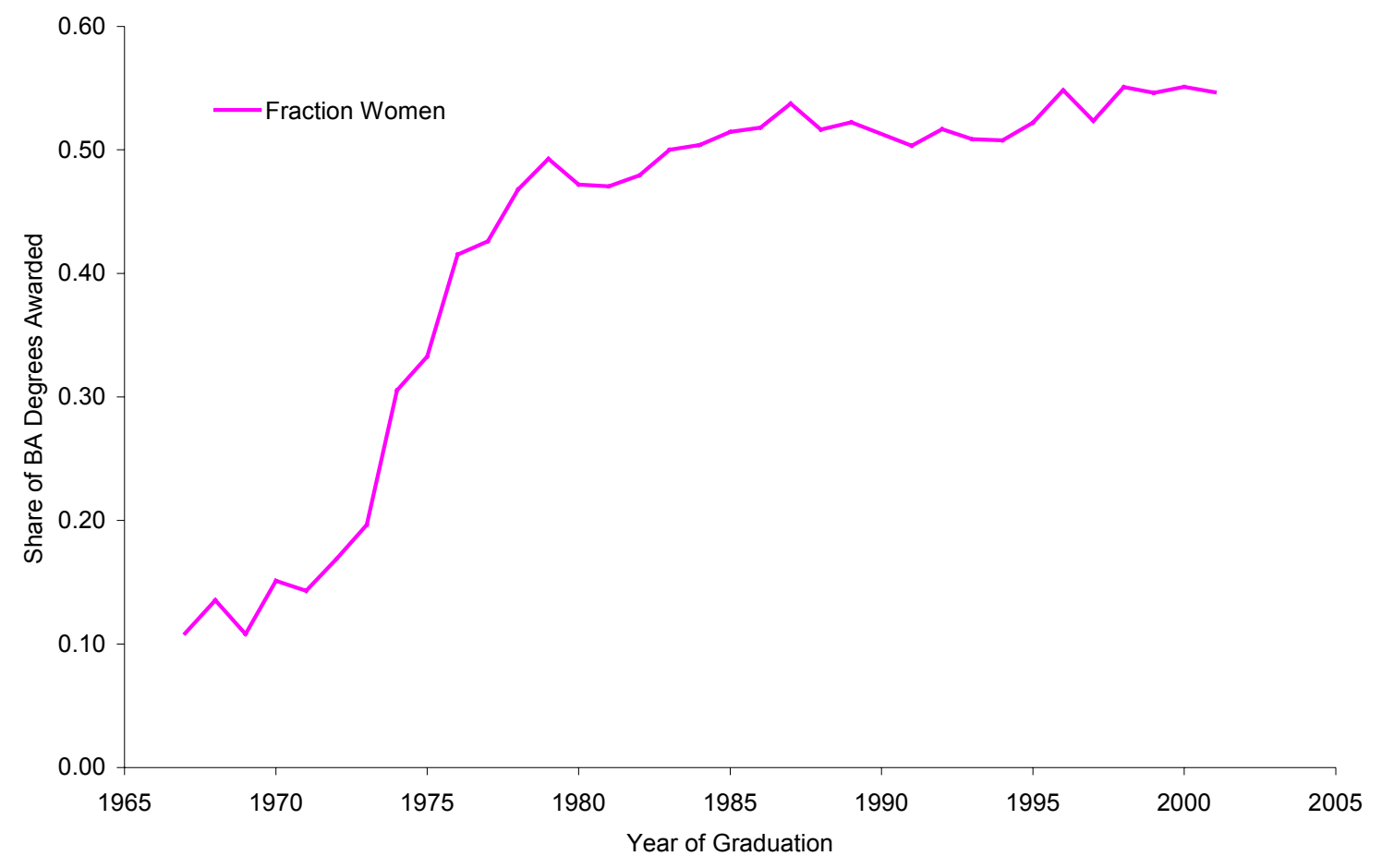

Source: Data from University of Virginia Institutional Assessment and Studies. 
Figure 3: Share of bachelors degrees awarded to African Americans at the University of Virginia.

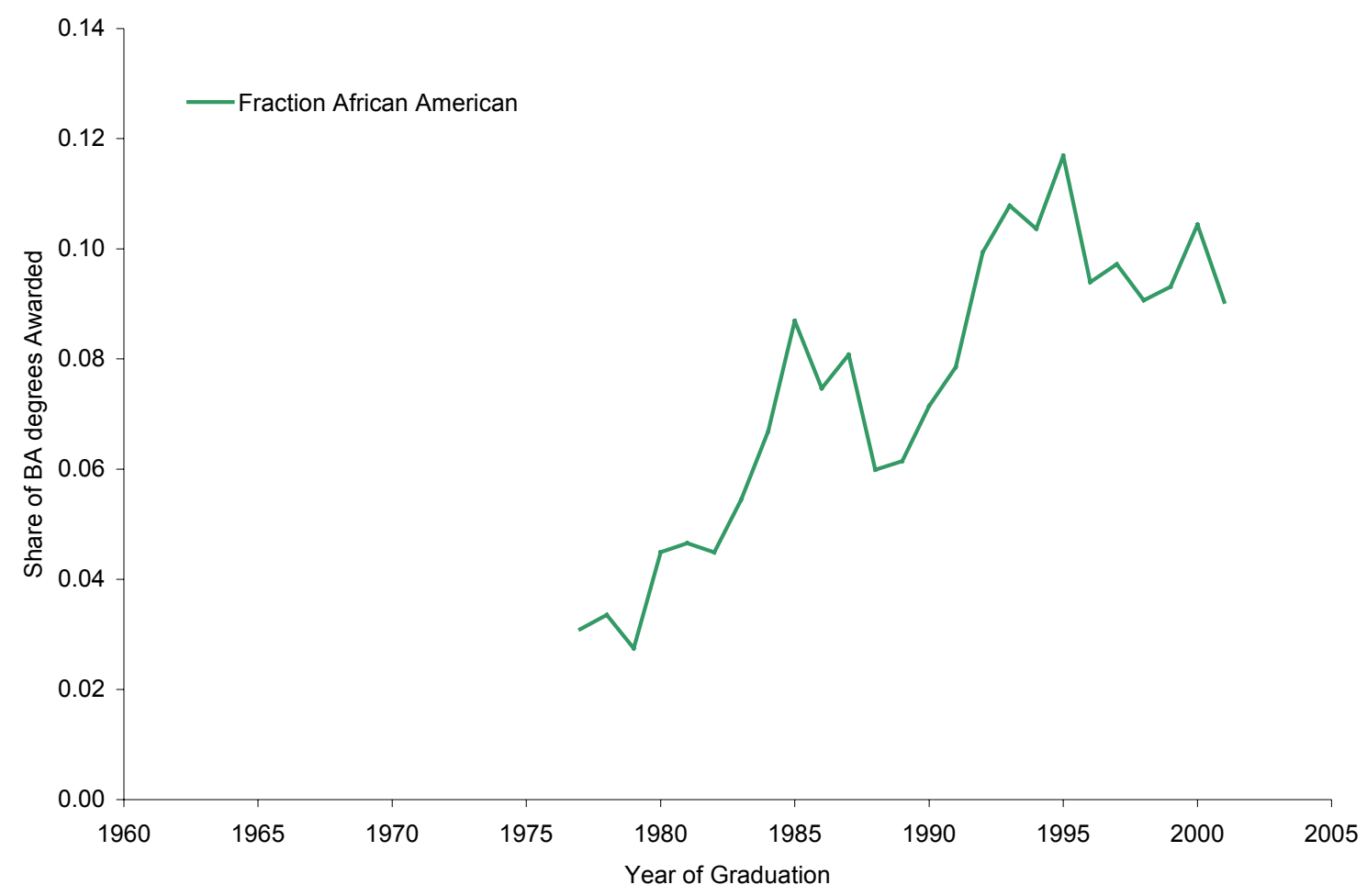

Source: Data from University of Virginia Institutional Assessment and Studies. 
Figure 4. Predicted size of the University of Virginia's potential legacy pool under various assumptions about alumni unions.

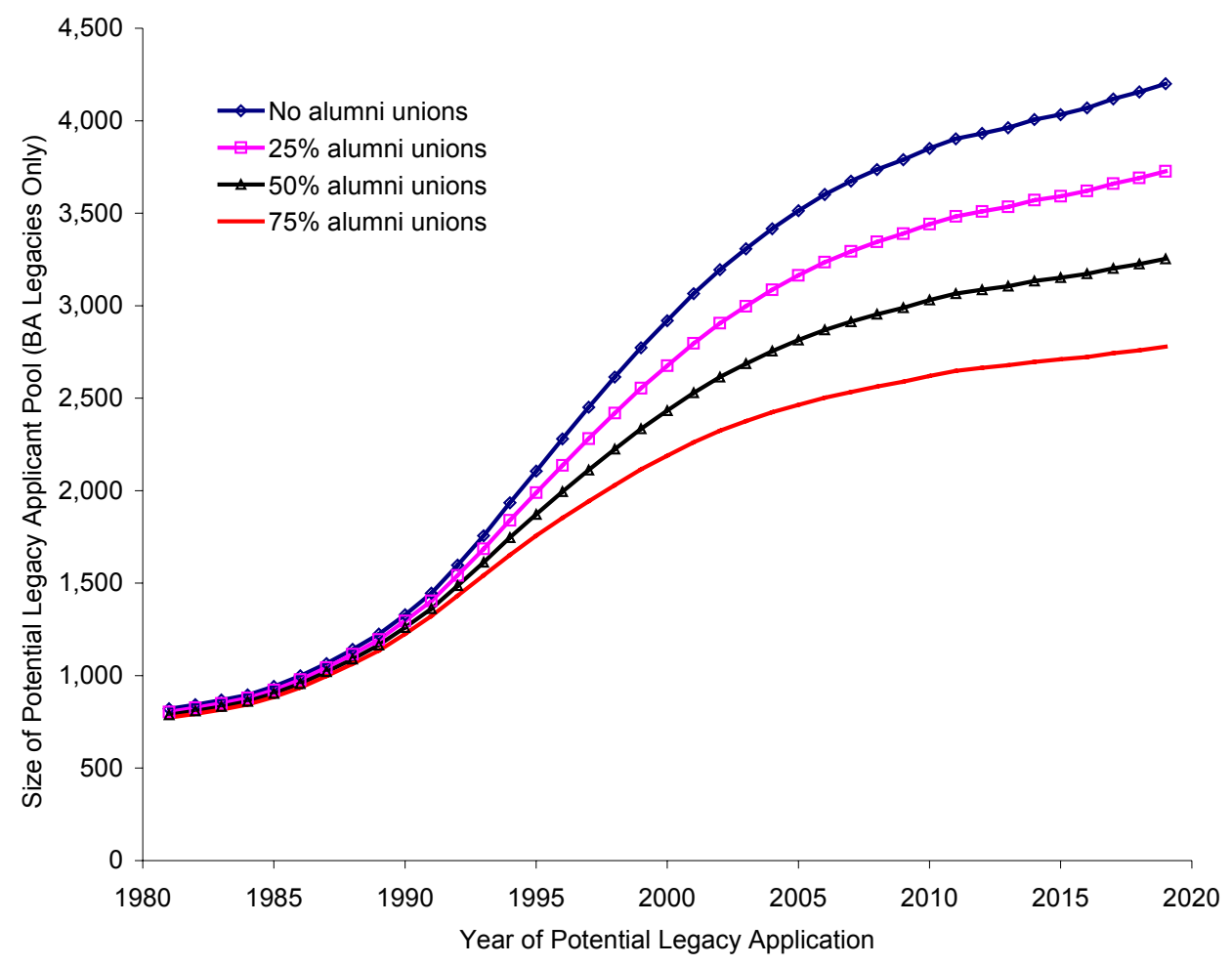


Figure 5. Predicted share of African Americans in the University of Virginia's pool of potential legacy applicants.

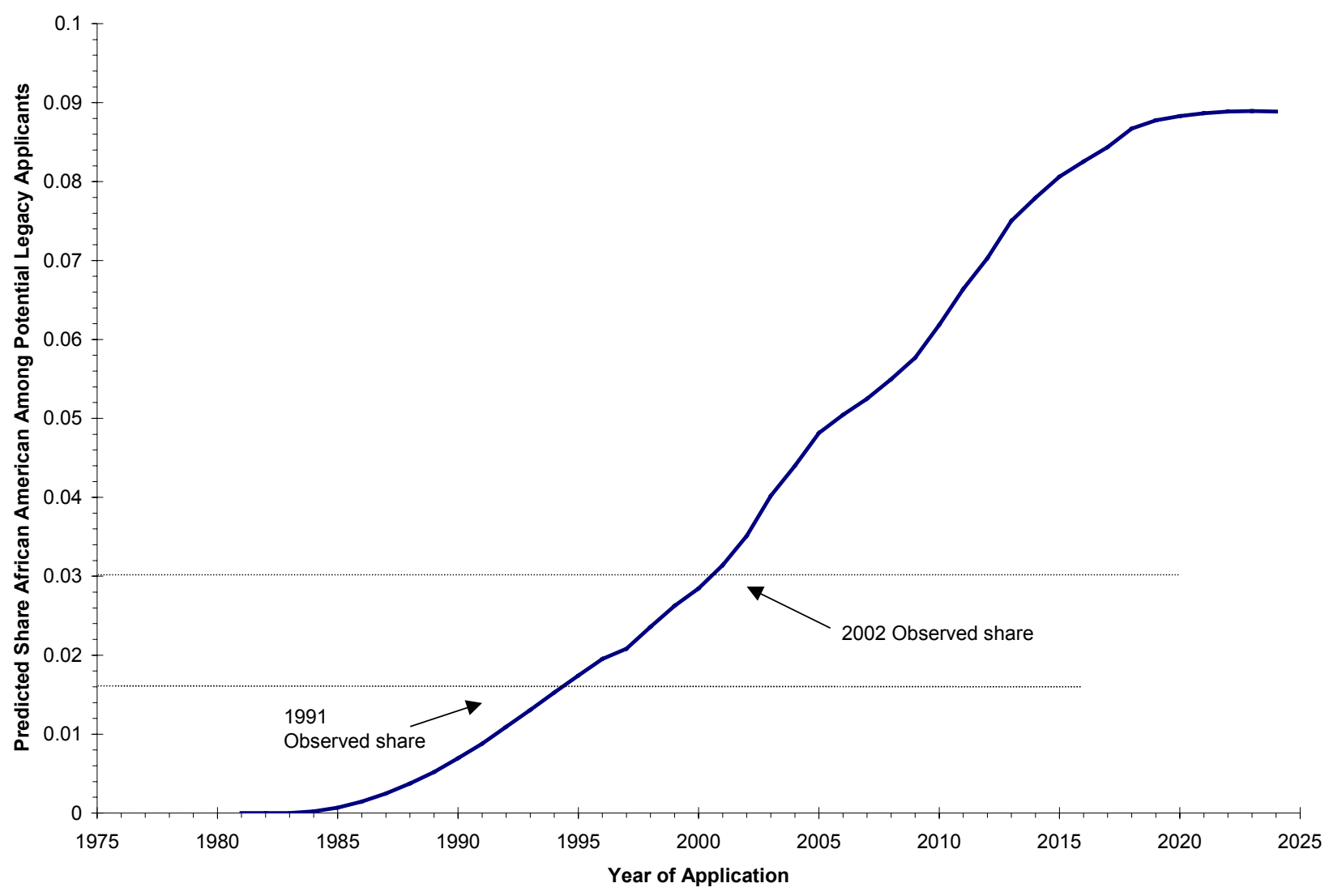

